\title{
Technical note: Coordination and harmonization of the multi-scale, multi-model activities HTAP2, AQMEII3, and MICS-Asia3: simulations, emission inventories, boundary conditions, and model output formats
}

\author{
Stefano Galmarini ${ }^{1}$, Brigitte Koffi ${ }^{1}$, Efisio Solazzo ${ }^{1}$, Terry Keating ${ }^{2}$, Christian Hogrefe ${ }^{3}$, Michael Schulz ${ }^{4}$, \\ Anna Benedictow ${ }^{4}$, Jan Jurgen Griesfeller ${ }^{4}$, Greet Janssens-Maenhout ${ }^{1}$, Greg Carmichael $^{5}$, Joshua Fu ${ }^{6}$, and \\ Frank Dentener ${ }^{1}$ \\ ${ }^{1}$ European Commission, Joint Research Centre, Ispra, Italy \\ ${ }^{2}$ Environmental Protection Agency, Applied Science and Education Division, National Center for Environmental Research, \\ Office of Research and Development, Headquarters, Federal Triangle, Washington, DC 20460, USA \\ ${ }^{3}$ Environmental Protection Agency, Computational Exposure Division, National Exposure Research Laboratory, \\ Office of Research and Development, Research Triangle Park, NC 27711, USA \\ ${ }^{4}$ Norwegian Meteorological Institute, Oslo, Norway \\ ${ }^{5}$ Center for Global and Regional Environmental Research, University of Iowa, Iowa City, IA 52242, USA \\ ${ }^{6}$ Department of Civil \& Environmental Engineering, University of Tennessee, Knoxville, TN 37996, USA
}

Correspondence to: Stefano Galmarini (stefano.galmarini@jrc.ec.europa.eu)

Received: 16 September 2016 - Published in Atmos. Chem. Phys. Discuss.: 18 October 2016

Revised: 14 December 2016 - Accepted: 3 January 2017 - Published: 31 January 2017

\begin{abstract}
We present an overview of the coordinated global numerical modelling experiments performed during 20122016 by the Task Force on Hemispheric Transport of Air Pollution (TF HTAP), the regional experiments by the Air Quality Model Evaluation International Initiative (AQMEII) over Europe and North America, and the Model Intercomparison Study for Asia (MICS-Asia). To improve model estimates of the impacts of intercontinental transport of air pollution on climate, ecosystems, and human health and to answer a set of policy-relevant questions, these three initiatives performed emission perturbation modelling experiments consistent across the global, hemispheric, and continental/regional scales. In all three initiatives, model results are extensively compared against monitoring data for a range of variables (meteorological, trace gas concentrations, and aerosol mass and composition) from different measurement platforms (ground measurements, vertical profiles, airborne measurements) collected from a number of sources. Approximately 10 to 25 modelling groups have contributed to each initiative, and model results have been managed centrally through three data hubs maintained by each initiative.
\end{abstract}

Given the organizational complexity of bringing together these three initiatives to address a common set of policyrelevant questions, this publication provides the motivation for the modelling activity, the rationale for specific choices made in the model experiments, and an overview of the organizational structures for both the modelling and the measurements used and analysed in a number of modelling studies in this special issue.

\section{Introduction}

The Task Force on Hemispheric Transport of Air Pollution (TF HTAP) was organized in 2005 under the UNECE Convention on Long-range Transboundary Air Pollution (CLRTAP) (see http://www.unece.org/env/lrtap/welcome.html). Recognizing the increasing importance of hemispheric transport of air pollution, CLRTAP mandated the TF HTAP to work in partnership with scientists across the world to improve knowledge on the intercontinental or hemispheric 
transport and formation of air pollution; its impacts on climate, ecosystems, and human health; and the potential mitigation opportunities.

In 2010, TF HTAP produced the first comprehensive assessment of the intercontinental transport of air pollution in the Northern Hemisphere (TF HTAP, 2010a, b). A series of four reports addressed issues around emissions, transport, and impacts of particulate matter and ozone, mercury, and persistent organic pollutants (POPs), as well as their relevance for policy. The HTAP Phase 1 (HTAP1) joint modelling experiments, in which more than 20 global models participated, focussed on the meteorological year 2001. In 2012, the TF HTAP launched a new phase of cooperative multi-model experiments and analyses to provide up-to-date information to CLRTAP (e.g. Maas and Grenfellt, 2016) and other multi-lateral cooperative efforts, as well as national actions to decrease air pollution and its impacts.

The objectives of the HTAP Phase 2 (HTAP2) activity are summarized as follows:

- to estimate relative contributions of regional and extraregional sources of air pollution in different regions of the world, by refining the source-receptor relationships derived from the HTAP Phase 1 simulations;

- to provide a basis for model evaluation and process studies to characterize the uncertainty in the estimates of regional and extra-regional contributions and understand the differences between models;

- to give input to assessments of the impacts of control strategies on the contribution of regional and extraregional emissions sources to the exceedance of air quality standards and to impacts on human health, ecosystems, and climate.

The major advances of HTAP2 over the earlier HTAP1 experiments were the following:

- A focus on more recent years as a basis for extrapolation (2008-2010), including an updated collection of emission inventories for 2008 and 2010 (JanssensMaenhout et al., 2015) that is utilized across all model experiments. In HTAP1 the year of interest was 2001, and in contrast to HTAP2, the anthropogenic emissions used by the different modelling groups were expected to be loosely representative for the beginning of the 2000s but were not prescribed, resulting in a large diversity of baseline emissions.

- An expanded number of more refined source/receptor regions: the original set of four rectangular (in latitudelongitude coordinates) source regions (North America, Europe, south Asia, and east Asia) identified in HTAP1 have been refined to align with geo-political borders, and additional regions have been added, dividing the world into 16 potential source regions and 60 receptor regions.
- The use of regional models and consistent boundary conditions from selected global models for Europe, North America, and Asia to provide high-resolution estimates of the impacts on health, vegetation, and climate, in addition to the global models' worldwide coverage.

The most innovative aspect of the modelling work, performed in 2013-2016, is the consistent coupling of global and regional model experiments using existing modelling frameworks. The regional counterparts of the HTAP2 activity are the AQMEII (Air Quality Model Evaluation International Initiative) and MICS-Asia (Model Intercomparison Study for Asia) activities.

The AQMEII project was launched in 2008 in an attempt to bring together modellers from both sides of the Atlantic Ocean to perform joint regional model experiments using common boundary conditions, emissions, and model evaluation frameworks with a specific focus on regional modelling domains over Europe and North America (Rao et al., 2012). The first two AQMEII activities focused on the development of general model-to-model and model-to-observation evaluation methodologies (phase 1; Galmarini et al., 2012a) and the simulation of aerosol-climate feedbacks with online coupled modelling systems (phase 2; Galmarini et al., 2015). AQMEII Phase 3 (AQMEII3) is devoted to performing joint modelling experiments with HTAP2. The AQMEII modelling community (Table 5) includes almost all of the major existing modelling systems for regional-scale chemical transport simulation in research and regulatory applications on both continents. Most of the groups participating are part of modelling initiatives in the individual European member states, and some of these groups utilize models developed in North America, thus providing the opportunity of assessing the application of these models outside of their conventional modelling context.

The MICS-Asia Phase III (MICS3) project is an activity building on work performed in phase I (1998-2000; sulfur transport and deposition) and phase II (2004-2009; sulfur, nitrogen, ozone, and aerosols; see Fu et al., 2008). MICS3 is organized as a multi-national consortium of institutions and brings together modellers from China, Japan, Korea, southeast Asia, and the United States (Table 6). The overall scope of MICS3 includes evaluation of the ability of models to reproduce pollutant concentrations under highly polluted conditions, dry and wet deposition fluxes, and the quantification of the effects of uncertainties due to process representation (emissions, chemical mechanisms, transport and deposition) and model resolution on simulated air quality. The joint evaluation with HTAP2 focuses on the evaluation of the role of long-range transport of air pollution both within and to/from east Asia on air quality and impacts on climate, ecosystems and human health.

The framework used for global aerosol modelling is the AeroCom initiative (Aerosol Comparison between observa- 
tions and models; Schulz et al., 2009; Myhre et al., 2013), and dedicated experiments on long-range transport were designed and performed in collaboration with HTAP as part of AeroCom phase 3 (see https://wiki.met.no/aerocom/ phase3-experiments), with an additional focus on long-range transport of dust and fire-derived aerosol. The data storage and evaluation platform for global models was shared between AeroCom and HTAP2 (see Sect. 2.5).

Presently these three activities involve 23 global-scale models (Table 3 ) and approximately 30 regional-scale modelling groups performing model simulations in the North American, European, and east Asian domains, probably making the HTAP2-AQMEII3-MICS3 exercise the largest multi-scale/multi-model activity ever performed in atmospheric chemical modelling. The multi-scale and multiregional modelling exercise required three independent organizations to manage and engage their respective communities and an overarching coordination effort as well as a high level of harmonization of the model simulations aiming at comparability, usability, and interoperability of the model results at the various scales. Specific decisions were made regarding the simulation period, lower air boundary conditions (emission inventory), volatile organic compound (VOC) speciation, methane concentrations, emission perturbation runs, source region perturbations, lateral and upper air boundary conditions for regional simulations, variables expected for the analysis, file naming conventions, type and location of monitoring sites where model results were output, data submission procedures, and the development and use of interoperable data archiving and visualization servers.

The scope of this note is to provide information on the modelling activity harmonization and coordination adopted to guarantee the maximum level of coherence between the global and regional simulations. It provides specific details on the organization of the global HTAP2 and the regional AQMEII3 activities, but only general information on the MICS3 experiments is provided. Additional details regarding HTAP2 are summarized at http://iek8wikis.iek. fz-juelich.de/HTAPWiki/ and are available in the report by Koffi et al. (2016) and for AQMEII3 at http://ensemble2.jrc. ec.europa.eu/aqmeii/.

This note provides coherent information on the simulations performed and their characteristics to support the analysis articles presented in this special issue.

\section{The HTAP2, AQMEII3, and MICS3 modelling exercises set-up}

The following aspects were harmonized in the organization of this multi-scale, multi-chemical-transport-model activity:

- Simulation periods and meteorology to be used.

- Emission inventories for global and regional models.
- Boundary conditions for regional-scale air quality models.

- Harmonization of global and regional model output and interoperability of data repositories to facilitate the exchange and analysis of model outputs.

- Monitoring data locations and methods for comparing models with observations.

- Documentation of individual model set-up and construction of ensemble averages.

\subsection{Simulation period and meteorology used}

The simulation period of interest 2008-2010 was chosen on the basis of the availability of emissions data and intensive observations. The models were requested to run the 3-year period with a priority given to the year 2010, followed by 2008 and then 2009. Global models can use meteorological data representative of the respective year, e.g. driven or constrained by one of the global analysis products that were most convenient to the modelling group. Regional-scale modellers also were free to use the meteorological model of their choice based on compatibility with their chemical transport model. Sets of chemical boundary conditions for the regional models were provided by a limited set of global models participating in the global modelling experiments (see Sect. 2.4)

\subsection{Emission data}

The anthropogenic emission data were harmonized across the regional and global modelling experiments. The Joint Research Centre's (JRC) EDGAR (Emission Database for Global Atmospheric Research) team - in collaboration with regional emission experts from the US Environmental Protection Agency (EPA), EMEP (European Monitoring and Evaluation Programme), CEIP (Centre on Emission Inventories and Projections), TNO (Netherlands Organisation for Applied Research), the MICS-Asia scientific community, and REAS (Regional Emission Activity Asia) - has compiled a composite of regional emission inventories with monthly grid maps that include EDGARv4.3 gap filling for regions and/or sectors that were not provided by the regional inventories.

The HTAP_v2.2 database (Janssens-Maenhout et al., 2015), used in the global modelling experiments, has the following characteristics:

- years 2008 and 2010, yearly and monthly time resolutions;

- components: $\mathrm{SO}_{2}, \mathrm{NO}_{x}$, non-methane VOC (NMVOC), $\mathrm{CH}_{4}, \mathrm{CO}, \mathrm{NH}_{3}, \mathrm{PM}_{10}, \mathrm{PM}_{2.5}, \mathrm{BC}$, and $\mathrm{OC}$ at sectorspecific level;

- seven emission sectors (Janssens-Maenhout et al., 2015); see Table 1; 


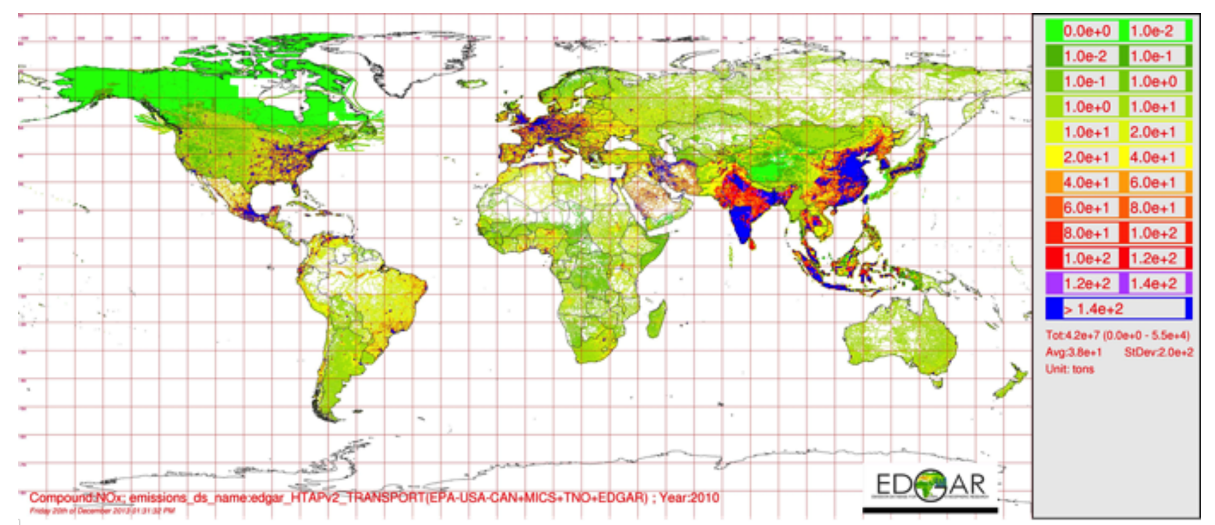

2010 NOx emissions from the transport sector (without aviation and ships)

Figure 1. Example of HTAP_v2.2 emission mosaics for $\mathrm{NO}_{x}$ in the transport sector.

- global coverage with spatial resolution of $0.1^{\circ} \times 0.1^{\circ}$ longitude and latitude, to serve the needs of both global and regional model activities.

Annual gridded emission data (http://edgar.jrc.ec.europa. eu/htap_v2) are delivered for each pollutant and emission sector. Monthly gridded values are provided for some sectors (energy, industry, transport, and residential), where information was available to disaggregate annual emissions. For 2009 no emissions were provided, leaving the choice to the modelling group to either interpolate the 2008 and 2010 data or leave them constant.

The regional emissions for the North American and European regional-scale simulations of AQMEII 3 are described in Pouliot et al. (2015), were used earlier for AQMEII2 (Galmarini et al., 2015), and are embedded into the HTAP_v2.2 inventory. The Asian inventory MIX (Li et al., 2015) was developed for MICS3 and HTAP2 simulations on a $0.25^{\circ} \times 0.25^{\circ}$ resolution and converted by raster resampling to $0.1^{\circ} \times 0.1^{\circ}$ resolution for use in HTAP2. These regional inventories have been combined to form a global mosaic (Fig. 1) that is consistent with inventories used at the regional scale in Europe, North America, and Asia. However, we note that these emission estimates stemming from different data sources for different regions of the world are not necessarily consistent with each other; for example different fuel statistics or emission factors may have been used for different regions. Details on the recommended VOC speciation and other specific emission information can be found in Koffi et al. (2016), Janssens Maenhout (2015), Li et al. (2015), and Pouliot et al. (2015).

Biomass burning emissions have not been prescribed for the global modelling groups, but it is recommended that groups use Global Fire Emission Database version 3 (GFED3) data, which are available at daily and $3 \mathrm{~h}$ intervals (see http://globalfiredata.org/). For the regional modelling groups participating in AQMEII3, fire emissions were included in the inventories distributed to the par- ticipants (Pouliot et al., 2015; Soares et al., 2015). Biogenic NMVOCs, soil and lightning $\mathrm{NO}_{x}$, dust, and sea salt emissions have not been prescribed for either the global or regional modelling groups; modelling groups are encouraged to use the best information that they have available, except that the AQMEII3 regional modelling groups were advised not to include lightning $\mathrm{NO}_{x}$ in their simulations since not all modelling groups had a mechanism for including them. For wind-driven DMS (dimethyl sulfide) emissions from oceans, the climatology of ocean surface concentrations described in Lana et al. (2011) was recommended in conjunction with the model's meteorology and emission parameterization for the global models. The regional models participating in AQMEII 3 did not consider DMS emissions. For volcanic emissions, it was recommended that global groups use the estimates developed for 2008-2010 for AeroCom as an update of the volcanic $\mathrm{SO}_{2}$ inventory of Diehl et al. (2012) and accessible at http:// aerocom.met.no/download/emissions/HTAP/. As in the case of lightning $\mathrm{NO}_{x}$ emissions, the AQMEII3 regional modelling groups were advised not to include volcanic emissions in their simulations since not all modelling groups had a mechanism for including them. Modelling groups were asked to document the source of all of their emissions data and assumptions, especially if it deviated from the recommended parameterizations. For mercury, the Arctic Monitoring and Assessment Programme (AMAP)/United Nations Environmental Programme (UNEP) global emissions inventory for 2010 was recommended (http://www.amap.no/ mercury-emissions). None of the regional models participating in AQMEII 3 considered mercury in their simulations.

\subsection{Emission perturbation}

In addition to the base 2008-2010 simulations, modelling groups were requested to perform emission perturbation experiments to help estimate source-receptor relationships; to attribute estimated concentrations, deposition fluxes, and de- 
Table 1. Emission sectors in HTAP_v2.2 database.

\begin{tabular}{ll}
\hline Sector & Description \\
\hline Air & International and domestic aviation \\
Ships & International shipping \\
Energy & $\begin{array}{l}\text { Power generation } \\
\text { Industry }\end{array}$ \\
& $\begin{array}{l}\text { Industrial non-power large-scale combustion emissions and } \\
\text { emissions of industrial processes and product use including solvents }\end{array}$ \\
\hline Transport & $\begin{array}{l}\text { Ground transport by road, railway, inland waterways, pipeline, } \\
\text { and other ground transport of mobile machinery; does not include } \\
\text { re-suspension of dust from pavements or tyre and brake wear }\end{array}$ \\
\hline Residential & $\begin{array}{l}\text { Small-scale combustion, including heating, cooling, lighting, cooking, and } \\
\text { auxiliary engines to equip residential and commercial buildings, service } \\
\text { institutes, and agricultural facilities and fisheries; solid waste } \\
\text { (landfills/ incineration) and wastewater treatment }\end{array}$ \\
\hline Agriculture & $\begin{array}{l}\text { Agricultural emissions from livestock and crop cultivation but not from } \\
\text { agricultural waste burning and not including savannah burning }\end{array}$ \\
&
\end{tabular}

Table 2. BASE and methane perturbation runs.

\begin{tabular}{lll}
\hline Simulation & $\begin{array}{l}\text { Global } \mathrm{CH}_{4} \\
\text { concentration } \\
\text { (ppbv) }\end{array}$ & Representative of \\
\hline BASE & 1798 & 2010 based on IPCC (2013) \\
CH4INC & 2121 & 2030 under RCP 8.5 \\
CH4DEC & 1562 & 2030 under RCP2.6 \\
\hline
\end{tabular}

rived impacts to regional and extra-regional sources; and to be used for scenario evaluations including uncertainties. Fig. 2 lists a large number of possible perturbation experiments; all except the methane perturbation experiments involve a $20 \%$ decrease in anthropogenic emissions similar to HTAP1. The choice of $20 \%$ was motivated by the consideration that the perturbation would be large enough to produce a sizeable impact (i.e. more than numerical noise) even at long distances while small enough to be in the near-linear atmospheric chemistry regime, assumptions which are subject to further analysis. The emission decreases are specified for combinations of pollutants, regions, and sectors.

To capture the impact of changing methane emissions in a single-year simulation, it is necessary to perturb the methane concentration instead of the emissions. The recommended perturbations (Table 2) are intended to cover the range of $\mathrm{CH}_{4}$ concentration changes associated with the Representative Concentration Pathway (RCP) scenarios used for the Intergovernmental Panel on Climate Change (IPCC) Fifth Assessment Report (AR5) (IPCC, 2013) for 2030. The highest priority was assigned to an increase of global $\mathrm{CH}_{4}$ concentrations to $2121 \mathrm{ppbv}$ (representative of RCP8.5). The next priority is assigned to a decrease of global $\mathrm{CH}_{4}$ concentrations to $1562 \mathrm{ppbv}$ (representative of RCP2.6).
The combination of global (all regions and sources) and regional perturbation experiments provides the necessary information to calculate the so-called RERER (response to extra-regional emission reductions) metric, using the information on the contribution of foreign emission perturbations relative to all worldwide emission perturbation to a change in region $i$.

$\operatorname{RERER}_{i}=\frac{\Sigma R_{\text {foreign }}}{\Sigma R_{\text {all }}}=\frac{R_{\text {global }}-R_{\text {region }, \mathbf{i}}}{R_{\text {global }}}$,

where $R_{\text {global }}$ is the global response of a quantity (e.g. surface $\mathrm{O}_{3}$ concentration) in the global $20 \%$ perturbation simulation (GLO) minus the value in the unperturbed simulation (BASE) and $R_{\text {region }}$ is the regional response of that quantity in the regional $20 \%$ emission perturbation simulation minus its value in BASE. The metric can be applied to a range of quantities, including surface concentrations, column amounts, and derived parameters.

A low (i.e. near 0) RERER value means that the signal within a region is not very sensitive to extra-regional emission reductions and that local concentrations (or column amounts, etc.) depend more on local emission reductions given the current distribution of anthropogenic and biogenic emissions. A high RERER value (i.e. near 1) suggests that local conditions are strongly influenced by emissions changes outside the region. In some circumstances, when emission reductions correspond to increasing concentrations (e.g. ozone titration by NO emissions), RERER can be larger than 1 .

\subsection{Boundary conditions for regional simulations}

One of the new aspects of HTAP2 experiments is the coupling of global and regional model simulations, including coupled emission perturbation studies. These common experiments are intended to enable examination of the effects 


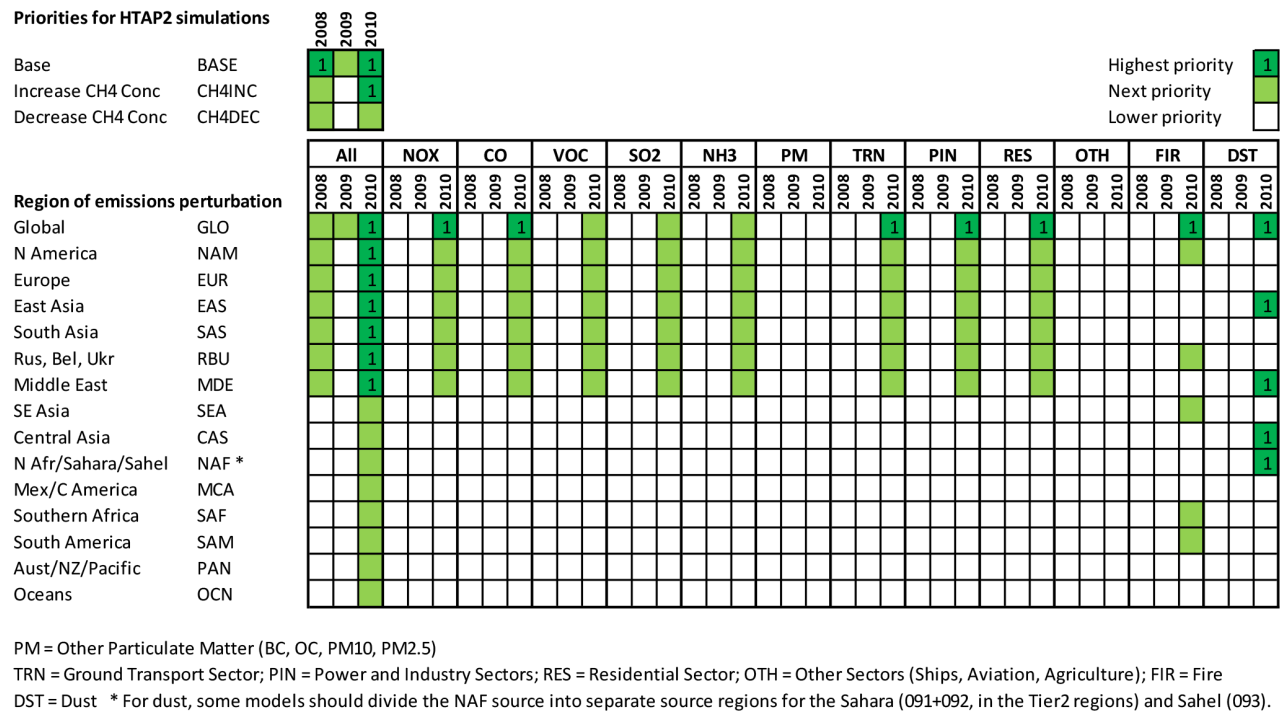

Figure 2. HTAP2 emission perturbation experiments; dark green colour with 1 are highest priority experiments, light green next priority, and white lower priority. ALL refers to perturbation of all anthropogenic components and sectors; sectors are TRN (transportation), PIN (power + industry), RES (residential), OTH (Other), FIR (fire), and DST (mineral dust).

Table 3. Global models and institutions participating in HTAP2.

\begin{tabular}{ll}
\hline Group/institution & Model \\
\hline CICERO & OsloCTM3.v2 \\
NASA GSFC & GOCARTv5 \\
RIAM & SPRINTARS \\
NAGOYA,JAMSTEC,NIES & CHASER_re1 \\
NAGOYA,JAMSTEC,NIES & CHASER_t106 \\
Univ.Col. Boulder & GEOS-Chem-ADJOINT \\
SSEC-NESDIS & RAQMS \\
SSEC_NESDIS & RAQMS_ASSIM \\
NASA GSFC & GEOS5 \\
GEORGIA TECH & REAM \\
SNU & GEOS-Chem \\
SNU & GEOS_Chem_Calnex \\
UNIMOD & EMEP_rv4.5 \\
UNIMOD & EMEP_rv4.8 \\
ECMWF & C-IFS \\
IITM & MOZART-4 \\
UTK & HCMAQ \\
NCAR & CAM-chem \\
Environment and Climate Canada & GEMMACH \\
UK Met Office & HadGEM2-ES \\
Iowa/JPL/GMU & STEM-CIFS \\
Iowa/JPL/GMU & STEM-GC \\
Iowa/JPL/GMU & STEM-RAQMS \\
\hline
\end{tabular}

of (a) finer spatial and temporal resolution of regional models and (b) different processes represented in global and regional models.

In order to "nest" the regional within the global simulations, computational results from one or more global models

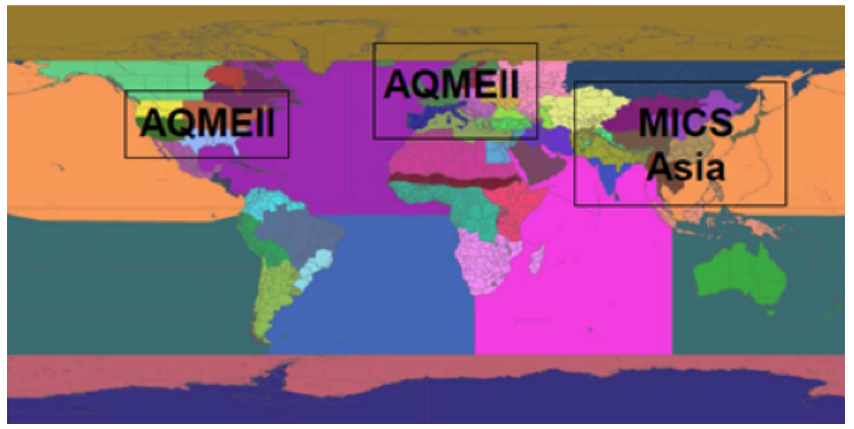

Figure 3. Domains of the regional model simulations and source/receptor areas.

are needed as boundary conditions for the regional models' domains (Fig. 3), typically provided as a set of time-varying concentrations of medium-to-long-lived components in a 3$\mathrm{D}$ box over the respective regional model domains at typical time resolutions of 3 to $6 \mathrm{~h}$.

A small number of the global models participating in HTAP2 provided boundary conditions for regional simulations, the choice depending mostly on existing experiences of regional communities with these particular global models. The global-scale simulations that were made available to the regional-scale modellers for defining boundary conditions are presented in Table 3. Boundary conditions were provided both for the BASE case and for a number of emission perturbation runs. Each of the emissions perturbation experiments with the global models created a new set of boundary conditions that can be used at the regional scale. This nesting is depicted graphically in Fig. 4. It shows an 


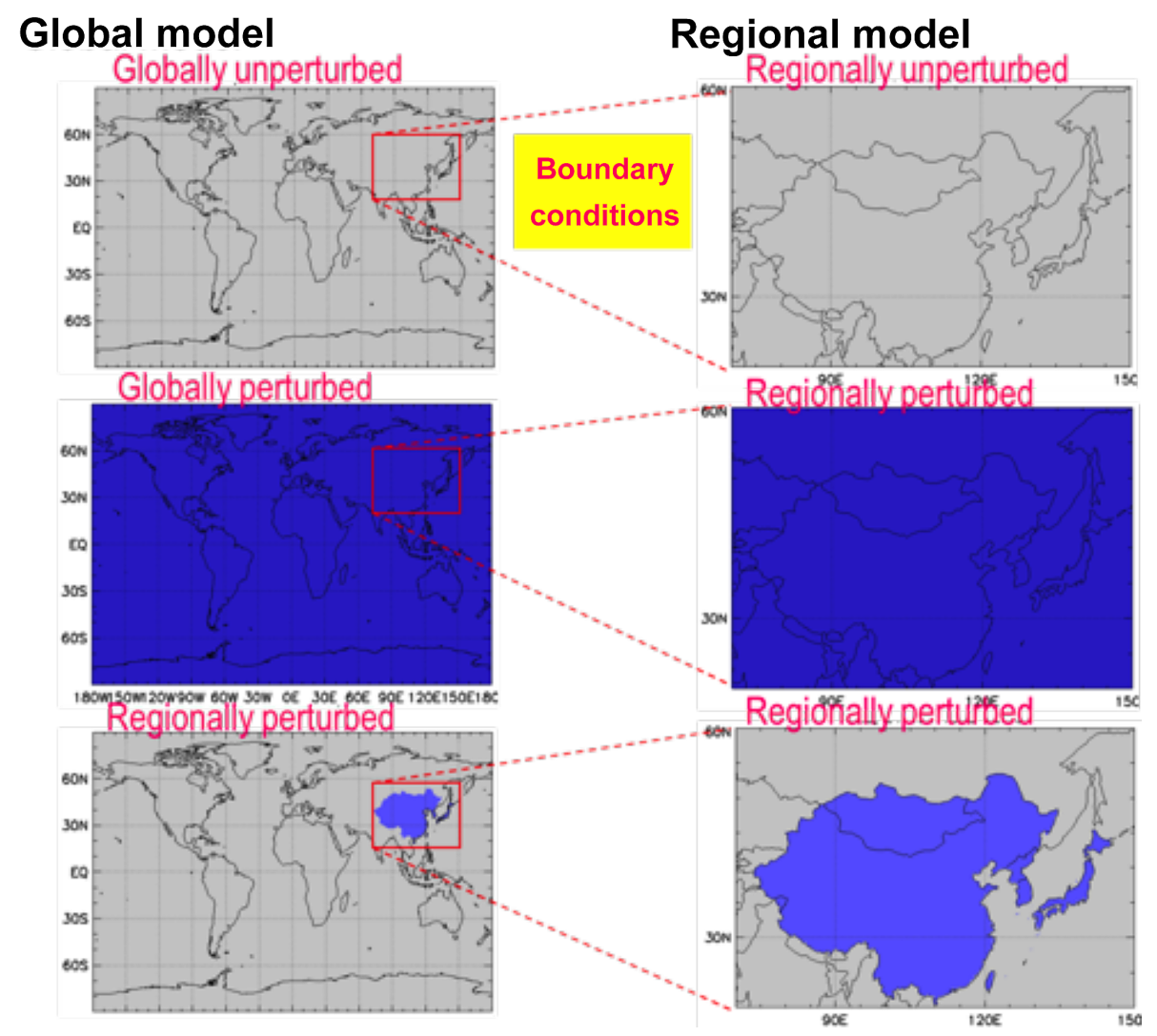

Figure 4. Example set of experiments, with both a global and regional model (in this case a regional model over east Asia, red box), where the regional source perturbation is east Asia (blue shading) and is wholly within the regional model domain. Note that the magnitude of the emission perturbation in the region of consideration is identical between the global and regional model.

example where the HTAP2 source region (in this case, east Asia) is wholly within the regional model domain. The inclusion of the global perturbation simulation (GLO scenario for all pollutants: GLOALL) allows consistent evaluation of the RERER metric for the $20 \%$ reductions of all emissions in both global and regional models (see Sect. 2.3).

Regional models were free to use as boundary conditions one or more models as long as they were selected from the set of global models participating in HTAP2, but in practice the AQMEII3 community focused its effort on C-IFS(CB05) (Flemming et al., 2015) calculations. Geophysical Fluid Dynamic Laboratory/Atmospheric Model 3 (GFDL/AM3; Lin et al., 2012a, b) and the Global Earth Observing System Chemistry model (GEOS-Chem; Park et al., 2004; Bey et al., 2001) were additionally used in some North American simulations. GEOS-Chem and CHASER (Sudo et al., 2002; Sudo and Akimoto, 2007; Watanabe et al., 2011; Sekiya and Sudo, 2014) were the preferred models for the MICS3 consortium.

\subsection{Specification of the global- and regional-scale model outputs}

Careful consideration was given to the organization of the model output, given the large number of models, vari- ables requested, and case studies. This required specifications of data formats, variable and file naming conventions, data organization at identified collection points, and the definition of agreed locations where measurements would be available and model data had to be produced for both regional and global models. Further details can be found at http://iek8wikis.iek.fz-juelich.de/HTAPWiki/ HTAP-2-data-submission and in Koffi et al. (2016). For HTAP2 and AQMEII3, the experience acquired over the past experiments allowed this massive data handling task to be carried out in an efficient way because data formats, naming conventions, and collections points were already well established for these two activities and respective communities of models. For HTAP2 the Network Common Data Form (netCDF; http://www.unidata.ucar.edu/ software/netcdf/) with Climate and Forecast (CF) (http: //cfconventions.org/) meta-data format was adopted. For AQMEII3 the ENSEMBLE data format was used (Galmarini et al., 2012b), allowing easy participation for regional modellers already participating in AQMEII2. Two data repositories were available for the two communities: the AeroCom repository at the Norwegian Meteorological Institute (MetNo) (aerocom.met.no; Schulz et al., 2009) and the JRC 
Table 4. 2008, 2009, and 2010 HTAP2 global runs for regional boundary conditions.

\begin{tabular}{|c|c|c|c|c|}
\hline Model & Spatial resolution & Temporal resolution & Chemistry & Simulations \\
\hline C-IFS(CB05) (ECMWF) & $\begin{array}{l}1.125^{\circ} \times 1.125^{\circ} \\
(\mathrm{T} 159) \\
54 \text { levels }\end{array}$ & 3 hourly & CB05 & $\begin{array}{l}\text { BASE } \\
\text { GLOALL } \\
\text { CH4INC } \\
\text { NAMALL } \\
\text { EURALL } \\
\text { EASALL } \\
\text { SASALL }\end{array}$ \\
\hline GFDL/AM3 & $\begin{array}{l}\sim 1^{\circ} \times 1^{\circ} \\
48 \text { levels }\end{array}$ & 3 hourly & & $\begin{array}{l}\text { BASE } \\
\text { GLOALL } \\
\text { CH4INC } \\
\text { NAMALL } \\
\text { EURALL } \\
\text { EASALL }\end{array}$ \\
\hline GEOS-Chem & $\begin{array}{l}2.5^{\circ} \times 2^{\circ} \\
47 \text { levels }\end{array}$ & 3 hourly & & $\begin{array}{l}\text { BASE } \\
\text { GLOALL } \\
\text { CH4INC } \\
\text { NAMALL } \\
\text { EURALL } \\
\text { EASALL }\end{array}$ \\
\hline CHASER & $2.8^{\circ} \times 2.8^{\circ}$ & 3 hourly + daily mean & & BASE \\
\hline
\end{tabular}

ENSEMBLE (Galmarini et al., 2014) platforms. Data for MICS3 modelling community were handled and analysed at the Joint International Center on Air Quality Modeling Studies (JICAM) in Beijing, China, a joint cooperation between the Institute of Atmospheric Physics (IAP) of the Chinese Academy of Sciences and the Asia Center for Air Pollution Research (ACAP) in Niigata, Japan. These facilities allow not only the organization of the data produced by various sources around the world but also their consultation through web interfaces and the matching of the model results with the available measured data and the statistical comparison of these two pieces of information. A connection and automatic data conversion protocol between the ENSEMBLE and AeroCom platforms was also pioneered to allow the bidirectional transfer of model data and a consistent comparison of global and regional model results with a common set of observations.

Global model data from this study can be accessed via the AeroCom data server at MetNo. Data are organized such that the HTAP2 model version, experiment, period, and variable name can be identified readily from directory and file names. Model output providers have to register at the database provider MetNo and are provided with access to a Linux server via ssh (see further details at https://wiki.met. no/aerocom/user-server). This server also provides essential and standard data inspection, analysis, and extraction tools for netCDF files (ncdump, ncview, python, nco, cdo, etc.). Users may utilize these tools to retrieve files or subsets of them for further analysis. All incoming files are processed with the AeroCom visualization tools to generate "quicklook" images for initial inspection. All variables are plotted as fields for major regions, each month and season. Where available, comparisons are made to surface observations, mainly those from the EBAS database maintained by the Norwegian Institute for Air Research (NILU, ebas.nilu.no) and from Aeronet (http://aeronet.gsfc.nasa.gov). The quicklook images are publicly available via the web interface at http://aerocom.met.no/cgi-bin/aerocom/surfobs_annualrs. $\mathrm{pl}$ ?PROJECT=HTAP\&MODELLIST=HTAP-phaseII-ALL .

To facilitate the comparability of model results with measured data, the former were requested as time series at surface locations, or vertical profiles, mostly located in $\mathrm{Eu}-$ rope and North America, enabling the comparison of the AQMEII3 and HTAP2 experiments. Model results were requested in various forms. Specifically, 4128 surface stations were identified for the comparison of gas phase species, 2068 surface stations were identified for the comparison of aerosol species, and 240 stations were identified for the evaluation of vertical profiles. These locations are a mixture of stations of global and regional significance and spatial representativeness (Fig. 5). Details of the data requests for HTAP2 can be found in Koffi et al. (2016).

For AQMEII3, the specifications of requested model variables are contained in the so-called AQMEII overarching document (http://ensemble2.jrc.ec.europa.eu/aqmeii/?page_ id=527). Model results are also available to participating modelling groups and the wider scientific community through the ENSEMBLE web-based platform following the 
Table 5. Institutions and models involved in AQMEII.

\begin{tabular}{|c|c|c|c|c|c|}
\hline Operated by & $\mathrm{RCM}$ & Emission & $\begin{array}{l}\text { Horiz. Res. } \\
\text { Lat x lon }\end{array}$ & Global Met & Chem Mod \\
\hline $\begin{array}{l}\text { Finnish Meteorological } \\
\text { Institute }\end{array}$ & $\begin{array}{l}\text { ECMWF- } \\
\text { SILAM_H, } \\
\text { SILAM_M }\end{array}$ & $\begin{array}{l}\text { EDGAR-HTAP; } \\
\text { TNO-MACC }\end{array}$ & $0.25 \times 0.25^{\circ}$ & ECMWF & CBM-IV \\
\hline $\begin{array}{l}\text { Netherlands Organisation } \\
\text { for Applied Scientific } \\
\text { Research }\end{array}$ & $\begin{array}{l}\text { ECMWF-L.- } \\
\text { EUROS }\end{array}$ & TNO-MACC & $0.5 \times 0.25^{\circ}$ & $\begin{array}{l}\text { Interpolation } \\
\text { from ECMWF }\end{array}$ & CBM-IV \\
\hline INERIS/CIEMAT & $\begin{array}{l}\text { ECMWF- } \\
\text { Chimere_H } \\
\text { Chimere_M }\end{array}$ & $\begin{array}{l}\text { EDGAR-HTAP; } \\
\text { TNO-MACC }\end{array}$ & $0.25 \times 0.25^{\circ}$ & $\begin{array}{l}\text { Interpolation } \\
\text { from ECMWF }\end{array}$ & MELCHIOR2 \\
\hline University of L'Aquila & $\begin{array}{l}\text { WRF- } \\
\text { WRF/Chem1 }\end{array}$ & TNO-MACC & $23 \mathrm{~km}$ & ECMWF & RACM-ESRL \\
\hline University of Murcia & $\begin{array}{l}\text { WRF- } \\
\text { WRF/Chem2 }\end{array}$ & TNO-MACC & $23 \mathrm{~km} \times 23 \mathrm{~km}$ & ECMWF & RADM2 \\
\hline Ricerca Sistema Energetico & WRF-CAMx & TNO-MACC & $23 \mathrm{~km} \times 23 \mathrm{~km}$ & ECMWF & CB05 \\
\hline University of Aarhus & WRF-DEHM & EDGAR HTAP & $50 \mathrm{~km} \times 50 \mathrm{~km}$ & ECMWF & Brandt et al. (2012) \\
\hline $\begin{array}{l}\text { Istanbul Technical } \\
\text { University }\end{array}$ & WRF-CMAQ1 & TNO-MACC & $30 \mathrm{~km} \times 30 \mathrm{~km}$ & NCEP & CB05 \\
\hline Kings College & WRF-CMAQ4 & TNO-MACC & $15 \mathrm{~km} \times 15 \mathrm{~km}$ & NCEP & CB05 \\
\hline Ricardo E\&E & WRF-CMAQ2 & TNO-MACC & $30 \mathrm{~km} \times 30 \mathrm{~km}$ & NCEP & CB05-TUCL \\
\hline $\begin{array}{l}\text { Helmholtz-Zentrum } \\
\text { Geesthacht }\end{array}$ & CCLM-CMAQ & EDGAR-HTAP & $24 \mathrm{~km} \times 24 \mathrm{~km}$ & NCEP & CB05-TUCL \\
\hline University of Hertfordshire & WRF-CMAQ3 & TNO-MACC & $18 \mathrm{~km} \times 18 \mathrm{~km}$ & ECMWF & CB05-TUCL \\
\hline $\begin{array}{l}\text { Helmholtz-Zentrum } \\
\text { Geesthacht }\end{array}$ & CCLM-CMAQ & SMOKE & $24 \mathrm{~km} \times 24 \mathrm{~km}$ & NCEP & CB05-TUCL \\
\hline $\begin{array}{l}\text { Environmental Protection } \\
\text { Agency of the USA }\end{array}$ & WRF-CMAQ & SMOKE & $12 \mathrm{~km} \times 12 \mathrm{~km}$ & NCEP (nudging) & CB05-TUCL \\
\hline RAMBOLL Environ & WRF-CAMx & SMOKE & $12 \mathrm{~km} \times 12 \mathrm{~km}$ & NCEP & CB05 \\
\hline University of Aarhus & WRF-DEHM & EDGAR-HTAP & $50 \mathrm{~km} \times 50 \mathrm{~km}$ & $\begin{array}{l}\text { interpolation } \\
\text { from ECMWF }\end{array}$ & Brandt et al. (2012) \\
\hline
\end{tabular}

Table 6. Institutions and models involved in MICS-Asia.

\begin{tabular}{ll}
\hline Group/institution & Models \\
\hline National Institute for Environmental Studies, Japan & CMAQv4.7.1 \\
Central Research Institute of Electric Power Industry, Japan & CMAQv4.7.1 \\
Kobe University, Japan & CMAQv4.7.1 \\
The University of Tennessee, Knoxville, USA & CMAQv5.0.2 \\
Sun Yat-Sen University, China (SYSU) & CMAQv5.0.2 \\
Institute of Atmospheric Physics, Chinese Academy of Sciences, China & GEOS-Chem \\
Institute of Atmospheric Physics, Chinese Academy of Sciences, China & NAQPMS \\
Meteorological Research Institute, Japan & NHM-Chem \\
Pusan National University, Korea (not in the analyses) & WRF-Chem \\
Academia Sinica, Taiwan (not in the analyses) & WRF-Chem \\
Institute of Atmospheric Physics, Chinese Academy of Sciences, China & RAMSCMAQ \\
Institute of Atmospheric Physics, Chinese Academy of Sciences, China (not in the analyses) & WRF-Chem \\
\hline
\end{tabular}

protocol established for phase 1 and 2 of AQMEII (Galmarini and Rao, 2011).

MICS3 output includes monthly averaged hourly surface data for $\mathrm{O}_{3}, \mathrm{NO}, \mathrm{NO}_{2}, \mathrm{HNO}_{3}$, and $\mathrm{HONO}$; surface VOC species consistent with the CB05, CBMZ, RADM2, and
SAPRC99 mechanisms; and wet/dry depositions of sulfur and nitrogen components.

To help diagnose the differences between models and isolate different transport processes, we requested that HTAP2 global models also include two passive tracers. These tracers 

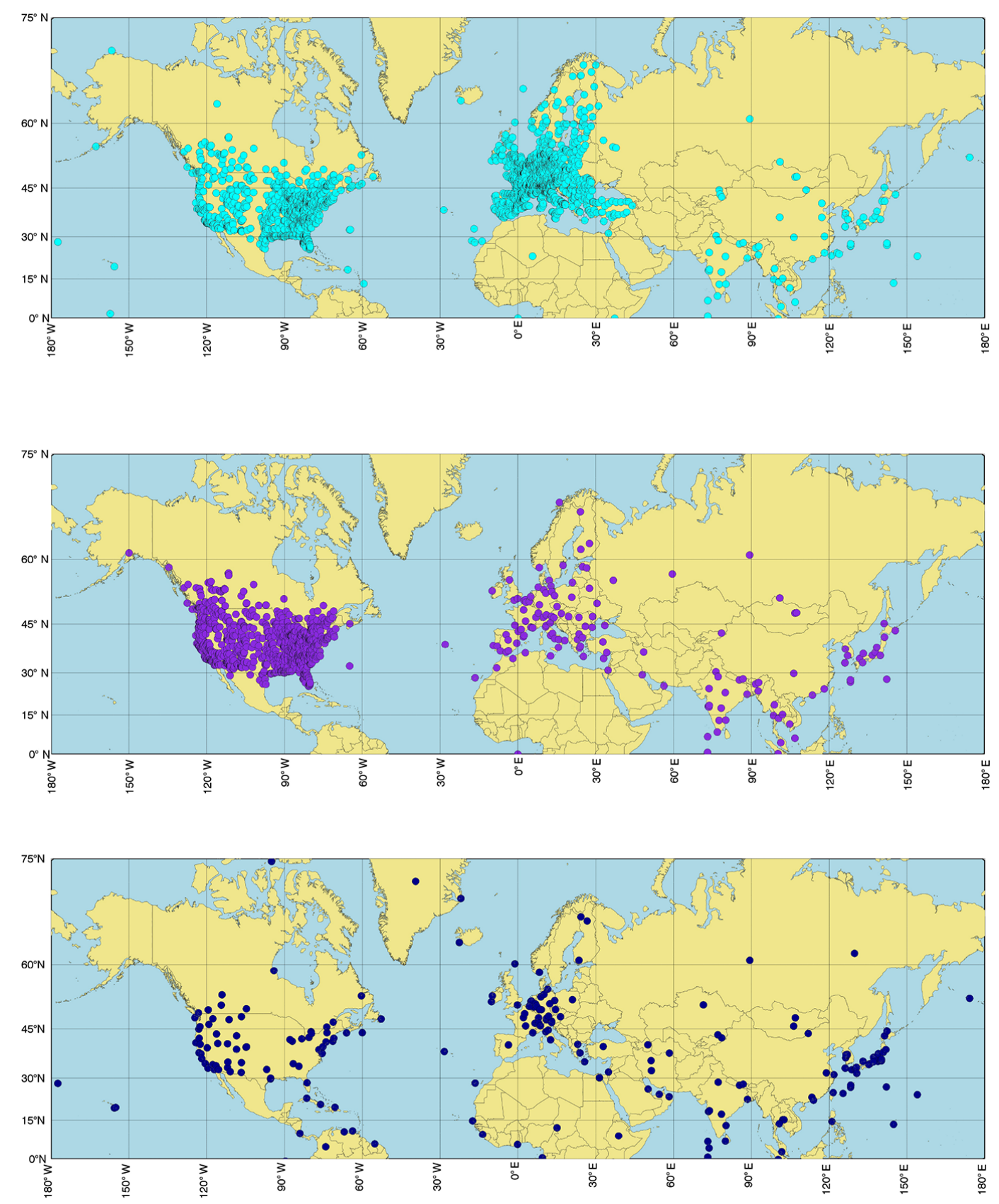

Figure 5. Location of the stations where surface gas (top), surface aerosol (middle), and vertical profile (bottom) model outputs are requested.

should be emitted in the same quantity as total anthropogenic $\mathrm{CO}$ emissions (not including fires) and decay exponentially with uniform fixed mean lifetimes (or e-folding times) of 25 and 50 days, respectively, as in the Chemistry-Climate Modelling Initiative (CCMI).

\section{Conclusions}

This technical note provides details about the set-up of the joint regional-global chemistry-transport emission perturba- tion experiments, planned and executed within the HTAP2 model exercise. The Task Force Hemispheric Transport Air Pollution falls under the Cooperative Programme for Monitoring and Evaluation of the Long-range Transmission of Air Pollutants in Europe (EMEP) of the UNECE Convention and is an increasingly important issue of hemispheric transport of air pollution. TF HTAP works in partnership with scientists across the world to improve our understanding of the intercontinental or hemispheric transport and formation of air pollution; its impacts on climate, ecosystems, and human 
health; and the potential mitigation opportunities. The major advances of HTAP2 with respect to previous HTAP1 activity are

- a focus on more recent years as a basis for extrapolation (2008-2010);

- a larger number of source/receptor regions;

- in collaboration with the existing regional-scale modelling initiatives AQMEII and MICS-ASIA, the use of regional models and consistent boundary conditions from selected global models for Europe, North America, and Asia to provide higher-resolution estimates of the impacts of hemispheric transport of air pollution on health, ecosystems, and climate.

The multi-model, multi-scale, and multi-pollutant character of the activities performed in HTAP2 required a considerable level of harmonization of the information used to run the models at different scales and of the results produced. Such harmonization considerably facilitates the interpretation of model results and inter-model differences. Particular attention was given to providing coherent emissions and boundary conditions to the global- and regional-scale models, and harmonizing monitoring data collected to evaluate the model results. To our knowledge such an attempt is unprecedented in the field and constitutes an important starting point for future multiple-scale modelling activities. A considerable effort has been made for the harmonization of data formats and webbased data hubs, allowing consultation of model and measurement data by the participants as well as possible external data users with simplicity and having a few "one-stop shops", where all information is collected, geo-referenced, and ready to be used. As independently demonstrated in the past, by the ENSEMBLE and AeroCom experiences, such an approach effectively takes away the burden on individual modelling groups of collecting scattered measurement data and organizing these data sets for comparison with models. Moreover, this approach effectively provides benchmark data sets for objective comparisons across models.

While first steps towards fuller integration of protocols, requested outputs, and analysis methods were shared across the three communities, a fully interoperable and harmonized set of global and regional outputs was not yet obtained due to different requirements of the communities. Data can now be converted into two of the three formats available very easily (HTAP $\Leftrightarrow$ AQMEII), and therefore the most important step to allow a full consultability of the data by the two communities has been made. The technical aspect of making the systems AeroCom and ENSEMBLE be mirrored into one another will also be explored in conjunction with available resources. All relevant elements are in place to make such steps possible. Such steps will also be performed possibly with the MICS-Asia data and information. At this stage, the availability of global and regional model outputs and observations at a common set of monitors permits a first analysis of globalregional model performance in the North American, European, and Asian domains and represents a significant step forward for both communities.

Many of the analyses presented in this special issue draw upon this unique collection of data and tools, which is open and available for further analysis. We encourage the scientific community to continue to explore these data to generate scientific and policy-relevant insights and to engage in the future development of the TF HTAP, AQMEII, and MICS-Asia activities.

\section{Data availability}

The data generated for the HTAP and AQMEII MICs-ASIA exercise are accessible through the data platforms described above upon contact with the managing organizations.

Competing interests. The authors declare that they have no conflict of interest.

Acknowledgements. The AeroCom database at MetNo received support from the CLRTAP under the EMEP programme, through the service contract to the European commission no. 07.0307/2011/605671/SER/C3, and benefitted from the Research Council of Norway project no. 229796 (AeroCom-P3). JRC received support for this work via Administrative Arrangement AMITO and AMITO2 from the European Commission DG Environment. TF HTAP, AeroCom, AQMEII, and MICS-Asia exist due to the relentless contributions of numerous excellent scientists actively engaged in the individual activities as well as in the wider TF programme. Although this work has been reviewed and approved for publication by the US Environmental Protection Agency, it does not necessarily reflect the views and policies of the agency. We thank Mian Chin for her support in designing and promoting the HTAP-AEROCOM experiments.

Edited by: B. R. D. Denby

Reviewed by: D. S. Stevenson and one anonymous referee

\section{References}

Bey, I., Jacob, D. J., Yantosca, R. M., Logan, J. A., Field, B. D., Fiore, A. M., Li, Q., Liu, H. Y., Mickley, L. J., and Schultz, M. G.: Global modeling of tropospheric chemistry with assimilated meteorology: model description and evaluation, J. Geophys. Res.-Atmos., 106, 23073-23095, 2001.

Brandt, J., Silver, J. D., Frohn, L. M., Geels, C., Gross, A., Hansen, A. B., Hansen, K. M., Hedegaard, G. B., Skjøth, C. A., Villadsen, H., Zare, A., and Christensen, J. H.: An integrated model study for Europe and North America using the Danish Eulerian Hemispheric Model with focus on intercontinental transport, Atmos. Environ., 53, 156-176, 2012. 
Diehl, T., Heil, A., Chin, M., Pan, X., Streets, D., Schultz, M., and Kinne, S.: Anthropogenic, biomass burning, and volcanic emissions of black carbon, organic carbon, and $\mathrm{SO}_{2}$ from 1980 to 2010 for hindcast model experiments, Atmos. Chem. Phys. Discuss., 12, 24895-24954, doi:10.5194/acpd-12-24895-2012, 2012.

Flemming, J., Huijnen, V., Arteta, J., Bechtold, P., Beljaars, A., Blechschmidt, A.-M., Diamantakis, M., Engelen, R. J., Gaudel, A., Inness, A., Jones, L., Josse, B., Katragkou, E., Marecal, V., Peuch, V.-H., Richter, A., Schultz, M. G., Stein, O., and Tsikerdekis, A.: Tropospheric chemistry in the Integrated Forecasting System of ECMWF, Geosci. Model Dev., 8, 975-1003, doi:10.5194/gmd-8-975-2015, 2015.

Fu, J. S., Jang, C. J., Streets, D. G., Li, Z., Kwok, R., Park, R., and Han, Z.: MICS-Asia II: Modeling gaseous pollutants and evaluating an advanced modeling system over East Asia, Atmos. Environ., 42 3571-3583, 2008.

Galmarini, S. and Rao, S. T.: The AQMEII two-continent Regional Air Quality Model evaluation study: Fueling ideas with unprecedented data, Atmos. Environ., 45, 2464, doi:10.1016/j.atmosenv.2011.03.025, 2011.

Galmarini S., Rao, S. T., and Steyn, D. G.: Preface to the AQMEII p1 Special issue, Atmos. Environ, 53, 1-3, 2012a.

Galmarini, S., Bianconi, R., Appel, W., Solazzo, E., Mosca, S., Grossi, P., Moran, M., Schere, K., and Rao, S. T.: ENSEMBLE and AMET: Two systems and approaches to a harmonized, simplified and efficient facility for air quality models development and evaluation, Atmos. Environ., 53, 51-59, 2012b.

Galmarini S., Hogrefe, C., Brunner, D., Makar, P., and Baklanov, A.: Preface to the AQMEII p2 Special issue, Atmos. Environ., $115,340-344,2015$.

IPCC, Climate Change 2013: The Physical Science Basis. Contribution of Working Group I to the Fifth Assessment Report of the Intergovernmental Panel on Climate Change, edited by: Stocker, T. F., Qin, D., Plattner, G.-K., Tignor, M., Allen, S. K., Boschung, J., Nauels, A., Xia, Y., Bex, V., and Midgley, P. M., Cambridge University Press, Cambridge, UK and New York, NY, USA, 1535 pp., 2013.

Janssens-Maenhout, G., Crippa, M., Guizzardi, D., Dentener, F., Muntean, M., Pouliot, G., Keating, T., Zhang, Q., Kurokawa, J., Wankmüller, R., Denier van der Gon, H., Kuenen, J. J. P., Klimont, Z., Frost, G., Darras, S., Koffi, B., and Li, M.: HTAP_v2.2: a mosaic of regional and global emission grid maps for 2008 and 2010 to study hemispheric transport of air pollution, Atmos. Chem. Phys., 15, 11411-11432, doi:10.5194/acp15-11411-2015, 2015.

Koffi B., Dentener, F., Janssens-Maenhout, G., Guizzardi, D., Crippa, M., Diehl, T., Galmarini, S., and Solazzo, E.: Hemispheric Transport Air Pollution (HTAP): Specification of the HTAP2 experiments - Ensuring harmonized modelling, EUR 28255 EN - Scientific and Technical Research Reports, doi:10.2788/725244, 2016.

Lana, A., Bell, T. G., Simó, R., Vallina, S. M., Ballabrera-Poy, J., Kettle, A. J., Dachs, J., Bopp, L., Saltzman, E. S., Stefels, J., Johnson, J. E., and Liss, P. S.: An updated climatology of surface dimethylsulfide concentrations and emission fluxes in the global ocean, Global Biogeochem. Cy., 25, GB1004, doi:10.1029/2010GB003850, 2011.
Li, M., Zhang, Q., Kurokawa, J., Woo, J.-H., He, K. B., Lu, Z., Ohara, T., Song, Y., Streets, D. G., Carmichael, G. R., Cheng, Y. F., Hong, C. P., Huo, H., Jiang, X. J., Kang, S. C., Liu, F., Su, H., and Zheng, B., MIX: a mosaic Asian anthropogenic emission inventory for the MICS-Asia and the HTAP projects, Atmos. Chem. Phys. Discuss., 15, 34813-34869, doi:10.5194/acpd-1534813-2015, 2015.

Lin, M. Y., Fiore, M., Horowitz, L. W., Cooper, O. R., Naik, V., Holloway, J., Johnson, B. J., Middlebrook, A. M., Oltmans, S. J., Pollack, I. B., Ryerson, T. B., Warner, J. X., Wiedinmyer, C., Wilson, J., and Wyman, B.: Transport of Asian ozone pollution into surface air over the western United States in spring, J. Geophys. Res.-Atmos., 117, D00V07, 2012a.

Lin, M., Fiore, A. M., Cooper, O. R., Horowitz, L. W., Langford, A. O., Levy II, H., Johnson, B. J., Naik, V., Oltmans, S. J., and Senff, C. J.: Springtime high surface ozone events over the western United States: Quantifying the role of stratospheric intrusions, J. Geophys. Res., 117, D00V22, doi:10.1029/2012JD018151, 2012b.

Maas, R. and Grennfelt P. (Eds.): EMEP Steering Body and Working Group on Effects of the Convention on Long-Range Transboundary Air Pollution, Towards Cleaner Air, Scientific Assessment Report, Oslo, xx, 50 pp., 2016.

Myhre, G., Samset, B. H., Schulz, M., Balkanski, Y., Bauer, S., Berntsen, T. K., Bian, H., Bellouin, N., Chin, M., Diehl, T., Easter, R. C., Feichter, J., Ghan, S. J., Hauglustaine, D., Iversen, T., Kinne, S., Kirkevåg, A., Lamarque, J.-F., Lin, G., Liu, X., Luo, G., Ma, X., Penner, J. E., Rasch, P. J., Seland, Ø., Skeie, R. B., Stier, P., Takemura, T., Tsigaridis, K., Wang, Z., Xu, L., Yu, H., Yu, F., Yoon, J.-H., Zhang, K., Zhang, H., and Zhou, C.: Radiative forcing of the direct aerosol effect from AeroCom Phase II simulations, Atmos. Chem. Phys., 13, 1853-1877, doi:10.5194/acp-13-1853-2013, 2013.

Park, R. J., Jacob, D. J., Field, B. D., Yantosca, R. M., and Chin, M.: Natural and trans- boundary pollution influences on sulfatenitrate-ammonium aerosols in the United States: implications for policy, J. Geophys. Res., 109, doi:10.1029/2011JD016961, 2004.

Pouliot, G., Denier van der Gon, H. A. C., Kuenen, J., Zhang, J., Moran, M. D., and Makar, P. A.: Analysis of the emission inventories and model-ready emission datasets of Europe and North America for phase 2 of the AQMEII project, Atmos. Environ., 115, 345-360, 2015.

Rao, S., Mathur, R., Hogrefe, C. Keating, T., Dentener, F., and Galmarini, S.: Path Forward for the Air Quality Model Evaluation International Initiative (AQMEII), EM, Air And Waste Management Associations Magazine For Environmental Managers, 7, 38-41, 2012.

Schulz, M., Chin, M., and Kinne S.: The Aerosol Model Comparison Project, AeroCom, Phase II: Clearing Up Diversity, IGAC Newsletter, No. 41, 2-11, 2009.

Sekiya, T. and Sudo, K.: Roles of transport and chemistry processes in global ozone change on interannual and multidecadal time scales, J. Geophys. Res., 119, 4903-4921, 2014.

Soares, J., Sofiev, M., and Hakkarainen, J.: Uncertainties of wildland fires emission in AQMEII phase 2 case study, Atmos. Environ., 115, 361-370, 2015.

Sudo, K. and Akimoto, H.: Global source attribution of tropospheric ozone: long-range transport from various source regions, J. Geophys. Res., 112, D12302, doi:10.1029/2006JD007992, 2007. 
Sudo, K., Takahashi, M., Kurokawa, J., and Akimoto, H.: CHASER: A global chemical model of the troposphere 1. Model description, J. Geophys. Res., 107, 7-20, doi:10.1029/2001JD001113, 2002.

TF HTAP (Task Force Hemispheric Transport of Airpollution): Part A, Ozone and Particulate Matter, in: Economic Commission for Europe, edited by: Dentener, F., Keating, T., and Akimoto, H., Air Pollution Studies, 17, UNECE, Geneva, 1-728, 2010a.

TF HTAP (Task Force Hemispheric Transport of Airpollution): Part D, Answers to Policy Relevant Science Questions, edited by: Keating, T., Zuber, A., Dentener, F., Seddon, J., Travnikov, O., Gusev, A., Carmichael, G., Parrish, D., and Grano, D., UNECE, Geneva, 2010b.
Watanabe, S., Hajima, T., Sudo,K., Nagashima, T., Takemura, T., Okajima, H., Nozawa, T., Kawase, H., Abe, M., Yokohata, T., Ise, T., Sato, H., Kato, E., Takata, K., Emori, S., and Kawamiya, M.: MIROC-ESM 2010: model description and basic results of CMIP5-20c3m experiments, Geosci. Model Dev., 4, 845-872, doi:10.5194/gmd-4-845-2011, 2011. 